\title{
METABOLISM OF WOMEN DURING THE REPRODUCTIVE CYCLE. XVII. CHANGES IN ELECTROPHORETIC PATTERNS OF PLASMA PROTEINS THROUGHOUT THE CYCLE AND FOLLOWING DELIVERY ${ }^{1,2}$
}

\author{
By MARGARET N. CORYELl, ELIOT F. BEACH, ${ }^{3}$ ABNER R. ROBINSON, \\ ICIE G. MACY, AND HAROLD C. MACK \\ (From the Research Laboratory, Children's Fund of Michigan, and The Department of \\ Obstetrics and Gynecology, Harper Hospital, Detroit)
}

(Submitted for publication July 17, 1950; accepted, August 28, 1950)

The present investigation, an electrophoretic study of blood proteins, was planned to obtain information concerning the preconceptional physiologic status of women, the physiologic changes in the maternal organism in preparation for the exigencies of labor and losses at delivery, for the readjustment during the puerperium, and the demands of lactation. The results of this study will provide the basis for a better understanding of electrophoretic determinations of the proteins in the blood of women whose child-bearing was complicated by abnormal conditions or disease (1).

While this investigation was in progress (2) the Tiselius procedure (3) for electrophoretic separation of blood proteins was applied to maternal, fetal, and infant sera by Longsworth, Curtis and Pembroke (4), Lagercrantz (5), Moore, DuPan and Buxton (6), and Scrimshaw and Alling (7) in studies of placental permeability and toxemias of pregnancy but, to our knowledge, this is the first report of electrophoretic determinations of constituents of the blood of healthy women throughout the reproductive cycle, from the preconceptional state through the postpartum readjustment period. The observations on cord blood will be presented in another communication.

\section{METHODS AND MATERIALS}

Healthy, well-nourished women in the early stages of gestation were selected from among his private patients

\footnotetext{
1 A preliminary report of the material in this paper was presented before the American Society of Biological Chemists at the 33rd Annual Meeting of the Federation of American Societies for Experimental Biology, Detroit, April 18-22, 1949.

2 This investigation was partially supported by a grant from The Nutrition Foundation, Inc., New York.

3 Present address: Biochemical Laboratory, Metropolitan Life Insurance Company, 1 Madison Ave., New York 10, N. Y.
}

by the obstetrician (H. C. M.) on the basis of medical history and examination. The subjects were average or above in economic level and leading normal family lives. They were consuming good diets and clinically were considered well-nourished before, during, and after pregnancy. Since longitudinal data have greater value than cross-sectional data under known environmental conditions during growth (8) and when a physiologic process is involved (9), insofar as possible the same subjects were studied before conception, and throughout pregnancy, delivery, and postpartum, thus providing both types of results and minimizing difficulties in interpreting individual differences by using each subject as her own "control." Data were obtained with the same techniques for a group of non-pregnant women who had never been pregnant.

\section{Blood sampling and preparation}

Blood samples for chemical determinations of total protein and for electrophoresis were obtained during the three trimesters of pregnancy, at delivery, and within 24 hours, five to six days, and six to 12 weeks postpartum. Samples were obtained from finger punctures for evaluation of nutritional status. Since the subjects were living at home and blood samples were procured at times of examination by the obstetrician, the women were not always in a fasting state when blood was withdrawn.

Blood was withdrawn from a vein in the antecubital fossa with minimum stasis which might affect the proteins (10), usually between 10:00 a.m. and 2:30 p.m. As accurately as possible, $20 \mathrm{ml}$. were drawn and discharged into a $50 \mathrm{ml}$., glass-stoppered Erlenmeyer flask containing $3 \mathrm{ml}$. of 2.5 per cent sodium citrate in physiologic saline solution. After mixing the contents thoroughly the flask was placed in a refrigerator pending transportation to the laboratory, usually less than two hours. At the laboratory the volume was measured with a calibrated pipette and the blood centrifuged under refrigeration for 30 minutes at 13,000 r.p.m.

\section{Determinations of total protein}

Total protein was estimated in aliquots of plasma from venous blood. The methods employed were the gravimetric acetone precipitation procedure (11) and the micro-Kjeldahl procedure (12) using 6.25 as the factor for converting nitrogen to protein and correcting the nitrogen value for non-protein-nitrogen by assuming an 
average content of $35 \mathrm{mg}$. in $100 \mathrm{ml}$. of plasma. In the calculation of data presented in this paper gravimetric data were used, except with a few samples for which values were not available.

\section{Electrophoretic technique}

The sodium barbital buffer solution recommended by Longsworth (13) as most suitable for analyses of human sera or plasma was used for dilution. Dialysis ${ }^{4}$ of plasma samples was continued for at least 72 hours at $4^{\circ} \mathrm{C}$. in preparation for electrophoretic study. The electrophoretic recordings were made with a Tiselius instrument 5 employing the Longsworth $(14,15)$ scanning mechanism and a three-piece Tiselius cell with a single long center section. Most determinations were run for three hours at $1^{\circ} \mathrm{C}$. and a potential gradient of about 6 volts $/ \mathrm{cm}$.

The patterns recorded on the original plates, both ascending and descending boundaries, were projected with a photographic enlarger and traced at a linear enlargement of approximately 2.16 times original size. On the tracings, the areas attributable to the various components were defined by the method of Tiselius and Kabat (16), in which ordinates are drawn from the lowest point between each two components to the base line. Each area was measured with a precision disc planimeter ${ }^{6}$ or a differential analyzer (17) and the relative concentrations were determined by dividing the areas representative of each component by the area of the entire pattern minus the area of the corresponding boundary anomaly. From this percentage figure and the chemically-determined value for the total plasma protein, corrected for dilution and shrinkage, the actual plasma concentrations of the respective components were calculated. The areas were computed from both the ascending and the descending boundaries, and the means used in calculating concentrations.

The ionic strength of buffer and blood sample, the protein concentration of the sample, and the type of buffer affect the values calculated for concentration of various protein components per $100 \mathrm{gm}$. of total protein from the electrophoretic data $(3,13,18)$. In this study these factors were controlled as closely as possible to enhance the accuracy of the albumin/globulin ratio and reduce variability in data owing to methods.

Boundary anomalies influence the electrophoretic mobilities and the relative distribution of the protein components $(5,13,19,20)$. Mobilities were calculated on the descending boundaries as advocated by Longsworth and MacInnes (21). Instead of the maximum gradients the ordinates dividing the respective areas in half were used as also suggested by these authors. The distances moved

${ }^{4}$ Nojax-Visking Cellulose Sausage Casing was used for dialysis. It was obtained from the Visking Corporation, 6733 West 56th Street, Chicago 31, Ill.

5 Klett Manufacturing Company, 179 East 87th Street, New York City, N. Y. Although the manufacturer's specifications indicated that the center section of the cell had a capacity of $11 \mathrm{ml}$., the actual size was $9+\mathrm{ml}$.

6 G. Gorado, Zurich, Switzerland. by the various peaks were measured from the salt anomaly, epsilon, instead of the starting boundary. In 28 samples of maternal plasma the mobilities were extremely constant, the ranges for albumin, alpha , alpha $_{2}$, beta, phi, and gamma being, respectively : 6.18-6.65; 5.10-5.61; 3.55$4.46 ; 2.92-3.40 ; 2.22-2.54$; and $1.28-1.58 \mathrm{~cm}^{2} / \mathrm{sec} . /$ volt $\times 10^{-5}$.

In addition to the chemical determinations, the total protein of dialyzed plasma samples was calculated from the total electrophoretic pattern areas as described by Abramson, Moyer and Gorin (22) and by Longsworth, Curtis and Pembroke (4). Plasma protein values obtained by either chemical or electrophoretic method were corrected for the diluting effect of the anticoagulant solution by calculations $(4,2.3)$.

According to data published by Dieckmann and Wegner $(24,25)$, the average ratios between hemoglobin and cell volume remain fairly constant throughout pregnancy and after gestation. Because of the rather large variation in hematocrit values, especially in pregnancy, it was felt that cell volumes calculated from the hemoglobin values on the basis of the average ratio, 0.34 , found by Wintrobe (26) would be more reliable than an average figure for cell volume.

In evaluating the significance of differences among results for blood from non-pregnant women and from subjects at various stages of pregnancy and postpartum, the "t test" for small samples (27) was employed after checking by the Chi Square test that the assumption of normal distribution for all the protein fractions was justified.

\section{Nutritional status determinations}

In blood samples obtained by the technique of Bessey and Lowry ${ }^{7}$ hemoglobin (28) and serum protein (29) were determined immediately after collection and preparation of the samples. Then, samples of serum and protein-free filtrates of serum were prepared and measured into microtubes, which were stored at $-30^{\circ} \mathrm{F}$. for determinations of vitamin $\mathrm{C}(30,31)$, alkaline phosphatase (32), vitamin A and carotenoids $(33,34)$.

\section{RESULTS AND DISCUSSION}

The subjects of this study were women of normal size, and their gestational weight gains ranged from 10 to 37 pounds. Ten to 21 subjects gained more than 25 pounds during pregnancy, which is frequently considered undesirable (35). The babies delivered by the mothers were all full term and healthy, none weighing less than 6 pounds at birth (36).

'The Research Laboratory of the Children's Fund of Michigan was extended the privilege by Drs. Otto A. Bessey and Oliver H. Lowry of sending a representative to the Medical Research Institute, Department of Health of the City of New York, for training in their microchemical blood techniques shortly after they were developed. 
The values for all components determined in the blood for ascertaining the nutritive state of the women were within the ranges considered to be normal for that period in the reproductive cycle. Hemoglobin ranged from 10.4 to $15.3 \mathrm{gm}$. per 100 $\mathrm{ml}$. of blood, with the highest values being found in samples obtained several weeks postpartum and the lowest values in samples for the second onehalf of pregnancy and in the first week postpartum. By the gradient tube micromethod, serum protein concentrations ranged from 5.45 to $7.20 \mathrm{gm}$. per $100 \mathrm{ml}$. Values for serum vitamin $\mathrm{C}$ varied widely, with values as low as 0.37 and as high as $2.78 \mathrm{mg}$. per $100 \mathrm{ml}$. From 1.0 to 9.7 nitrophenol units (millimoles nitrophenol formed per liter per hour) of alkaline phosphatase were found. Values as high as 9.7 units are not uncommon in the later weeks of pregnancy (37), as will be confirmed in a subsequent publication (38). Levels of vitamin $\mathrm{A}$ and carotenoids were within the ranges usually found.

Data from determinations of total protein and electrophoresis of the protein fractions in all samples of plasma from non-pregnant women and mothers during the reproductive cycle are summarized $^{8}$ in Table I. Electrophoresis values for individual proteins are given per $100 \mathrm{gm}$. of plasma protein and per $100 \mathrm{ml}$. of plasma.

The average values for total protein decreased somewhat during pregnancy, being 13 per cent below the non-pregnant value in the third trimester. The effect of this change with those protein components which decreased in concentration per $100 \mathrm{gm}$. of protein during pregnancy would be to emphasize the decrease on the basis of 100 $\mathrm{ml}$. of plasma, whereas for components which increased during pregnancy, the increase would be less marked on the basis of concentration per 100 $\mathrm{ml}$. of plasma. The increases in plasma volume which are known to occur during pregnancy also would tend to widen the differences between values on the basis of concentration in protein and in plasma.

Values from determinations in 22 samples of plasma from 12 healthy non-pregnant women are given first in the table. Two of the women gave

\footnotetext{
8 Results of determinations for the individual women will be included in the publication presenting the complete results of the study of maternal nutrition during the reproductive cycle.
}

four blood samples at weekly intervals in the ovulation cycle. One of these (Subject 23) subsequently became pregnant, providing the opportunity to study the changes in her electrophoretic pattern during the reproductive cycle in relation to her own preconceptional pattern. Since all of the values obtained for a single individual represent her plasma protein pattern over a period of time, all determinations for the same individual were averaged and the results used in calculating the means for the 12 individuals.

Other investigators have reported values for protein components of serum and plasma obtained by several methods. In total protein, the mean concentrations for non-pregnant women given in Table I compare favorably with those found for 15 normal adult males by Dole and Braun (39), although the values for alpha $a_{2}$ globulin and fibrinogen are, roughly, 15 and 20 per cent higher, respectively, than they reported. The values also agree well with those obtained by Armstrong, Budka and Morrison (20) with 20 pooled samples of plasma from normal subjects. On the basis of plasma concentration, the data for protein components reported by Dole and Braun were lower than those given in the table. Lagercrantz (5), using a refractometric method, found an average serum protein value of $7.61 \mathrm{gm}$. per $100 \mathrm{ml}$. for 16 normal women and with a colorimetric method a mean of $7.42 \mathrm{gm}$. per $100 \mathrm{ml}$. plasma was found for 15 normal young women by Plass and Matthew (40). The total serum protein of maternal blood determined from the total pattern area by Longsworth, Curtis and Pembroke (4) averaged 7.17 gm. per $100 \mathrm{ml}$.

The plasma albumin/globulin ratios for nonpregnant women cover a rather wide range, with a mean value lower than the 1.53 reported by Dole and Braun (39), and 1.48 by Plass and Matthew (40). The ratios plotted in Figure 1 for each period in the reproductive cycle show the decreases consequent to lowered albumin concentration and higher globulin concentration during pregnancy, with the return postpartum toward the non-pregnant relationship.

The individual determinations for the various subjects during their reproductive cycles portrayed variations attributable to differences among the women and the times in the cycle that the blood samples were drawn. For one woman (Sub- 


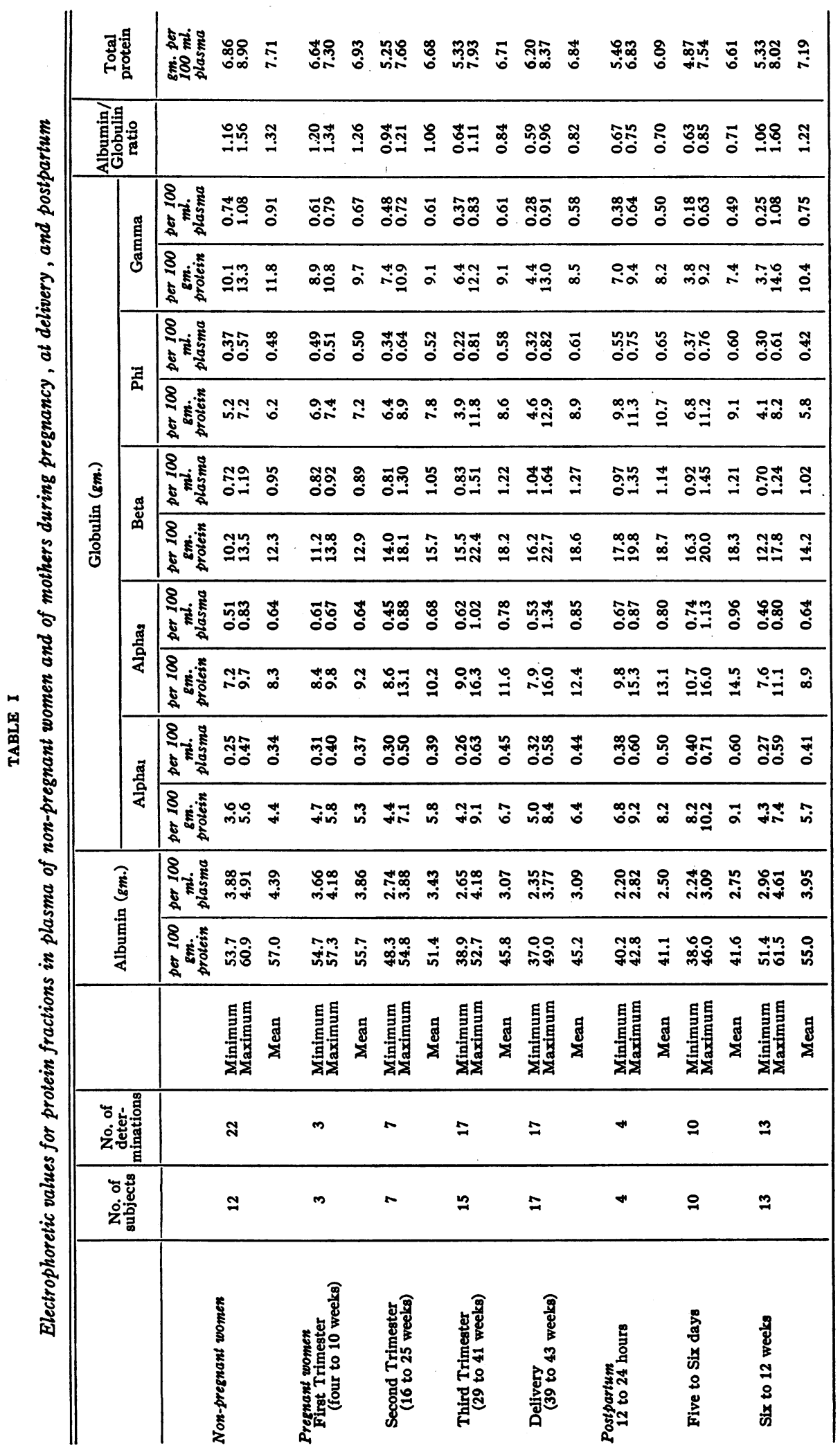


ject 23) four blood samples taken at weekly intervals between the two menstrual periods immediately prior to pregnancy were analyzed; after conception, samples were analyzed in each trimester of pregnancy, at delivery, and at three intervals postpartum. The ascending electrophoretic patterns obtained for this subject at the latest preconceptional time, throughout the cycle, and in the cord blood are reproduced in Figure 2. With these longitudinal results it has been possible to compare the changes in the plasma proteins of the same woman from the preconceptional state through postnatal readjustment with the mean cross-sectional values for all subjects during pregnancy, the puerperium, and subsequently.

The distributions of the components in the protein showed a remarkable conformance between the patterns for one woman and those of the means for all subjects, especially between the preconceptional pattern of Subject 23 and that of the means for 12 non-pregnant women. On the basis of plasma composition the distributions of the protein fractions corresponded, but greater variation was apparent between the levels for Subject 23 and the means for the group. Although this woman's values follow the trends of the group averages they are not always of the same magnitude.

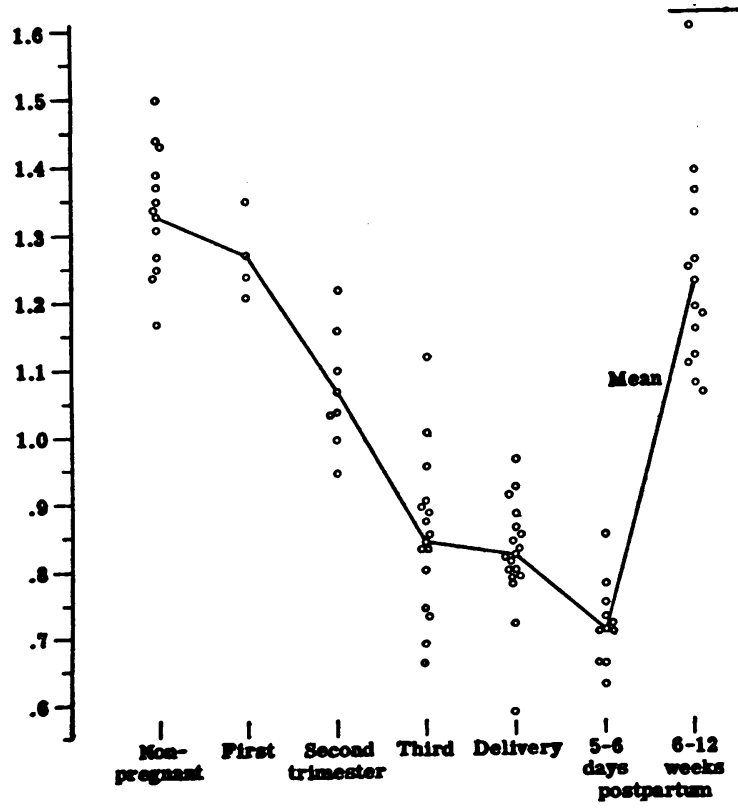

Fig. 1. Albumin/Globulin Ratios During the Reproductive CyCle

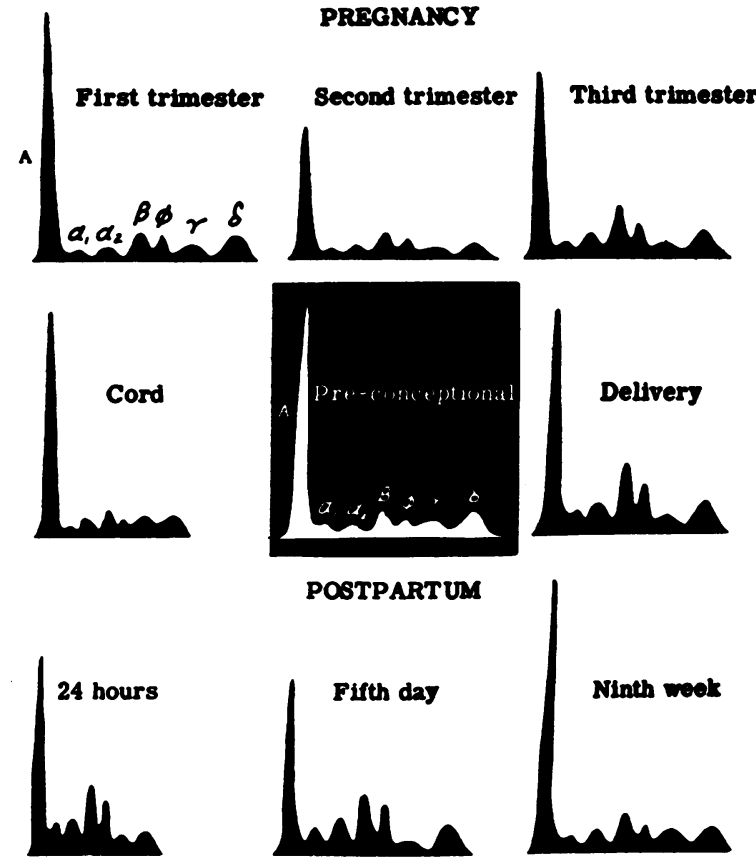

Fig. 2. Electrophoretic Patterns of the Plasma of One Woman Before Conception, During Pregnancy, and Postpartum; and of Her Cord Blood

That the unusual degree of conformance of the data for Subject 23 with those for the group was coincidental was demonstrated by other individual variations and emphasizes the importance of learning more about the individual physiological characteristics of different women as they proceed through the reproductive cycle. Her greater variation from the means for the group on the basis of concentration in plasma probably is attributable to individual variation of the blood volume of Subject 23 from the mean volume of the group.

The changes in plasma protein composition during reproduction were compared by the differences of means during pregnancy and postpartum from the mean values for all non-pregnant subjects. The results of statistical calculations of the significance of the differences were determined. In general, trends for albumin and gamma globulin were downward and for alpha ${ }_{1}$, alpha ${ }_{2}$, beta, and phi (fibrinogen) globulins were upward until delivery or later. Subsequently, the trends were reversed and values approached those of the nonpregnant state.

During the first trimester of pregnancy the decreases in albumin and gamma globulin were sta- 
tistically significant on the basis of plasma concentration, but per $100 \mathrm{gm}$. of total protein only the decrease in gamma globulin was significant. The increases in the other four protein fractions were not significant per $100 \mathrm{ml}$. of plasma but for alpha $_{1}$, alpha ${ }_{2}$, and phi globulins, the increases per $100 \mathrm{gm}$. of protein were significant.

In the second trimester the concentrations of albumin and gamma globulin in total protein and in plasma were reduced significantly. The increases in the other components were statistically significant in terms of total protein but were not in terms of plasma.

All differences for the final trimester were significant in relation to non-pregnant values, and for albumin, alpha $a_{2}$, and beta globulin the differences from second trimester values were significant, on the bases of both protein and plasma concentrations.

At delivery, also, all differences from non-pregnant values were significant and none of the means showed any significant deviation from those of the third trimester. The fact that differences between mean values at delivery were not significant from those for the third trimester, on the basis of concentrations in either total protein or plasma, would not support the report (41) of a large decrease in plasma volume during the final weeks of pregnancy, since changes in the concentration of total protein were variable and the means in the third trimester and at delivery differed by less than 2 per cent. The results conform with those of McLennan and Corey (42) who found that "the mean value at term was not significantly lower than that at the 36th week," and that all women did not show a reduction in plasma volume prior to delivery.

The average values for the concentrations in maternal plasma at delivery compare well with results for comparable subjects reported recently by Longsworth and his associates (4), obtained under almost identical experimental conditions, recognizing that they recorded all data in terms of serum, which would make the relative values 5 to 6 per cent higher owing to exclusion of the fibrinogen present in the samples.

Mean values for albumin and alpha ${ }_{1}$ globulin in the first day postpartum varied significantly from means at delivery on the basis of protein distribution, but in plasma only the variation in albumin concentration was meaningful by the statistical determination. The small number of determinations for this period limits the value of the averages but the values are interesting in relation to the results for five to six days after delivery.

Determinations on the fifth and sixth days after delivery did not show any significant differences from values for the first day postpartum, but the differences from values at delivery were significant for albumin and alpha $a_{1}$ globulin on both the protein and plasma bases. In addition, the mean for alpha $_{2}$ globulin concentration in total protein five to six days postpartum was significantly different from the figure for delivery. All components varied significantly from the non-pregnant values.

The means of the determinations six to 12 weeks postpartum were significantly different in all instances except one, on both the basis of total protein and of plasma, from the values for five to six days postpartum and those at delivery. By that time after delivery only the mean for albumin per $100 \mathrm{ml}$. plasma and the means for alpha ${ }_{1}$ globulin per $100 \mathrm{gm}$. protein and per $100 \mathrm{ml}$. plasma, and beta globulin per $100 \mathrm{gm}$. protein were significantly different from the means for non-pregnant women.

Through pregnancy to five to six days thereafter, total protein values were irregularly lower than those found for non-pregnant women, with decreases in some components opposed to increases in others. In evaluating plasma protein changes during the reproductive cycle consideration must be given to the fact that reductions in concentration of total protein in plasma do not indicate a decrease in total circulating protein because of the known increases in blood volume during pregnancy. We have emphasized individual physiologic differences which must be recognized and which may influence interpretations of mean values for a group of subjects.

Quantitatively, the decrease in albumin was largest, the mean values five to six days postpartum ( $2.75 \mathrm{gm}$. per $100 \mathrm{ml}$. plasma) being 1.64 gm. lower than the average (4.39 gm.) for nonpregnant women. The mean concentration of gamma globulin also was lower during pregnancy, from $0.91 \mathrm{gm}$. per $100 \mathrm{ml}$. of plasma in nonpregnant subjects to $0.49 \mathrm{gm}$. per $100 \mathrm{ml}$. five to six days after delivery. Although this fraction is known to carry many of the antibody materials of 
the blood and, in general, immunity may be related to quantity of the globulin, it is probable that immunity is related specifically to the peculiar characteristics of only a portion of that fraction. Reduction of gamma globulin and albumin in plasma is usually associated with dietary protein deficiency but observations and histories indicated that the subjects of this study consumed liberal amounts of protein during pregnancy, which would indicate that the changes in plasma protein are attributable to physiologic alteration of metabolism in pregnancy rather than to protein lack as such.

All the other globulin fractions rose in pregnancy, generally reaching their maximum near delivery. The mean for alpha ${ }_{1}$ globulin, which rose regularly in pregnancy, exceeds that for gamma globulin at five to six days postpartum. Of interest in this connection are the observations of Chanutin and Gjessing $(43,44)$, who, in dogs suffering traumatic injury or destruction of tissue by injection of nitrogen mustards, observed a fall in plasma albumin and a rise in the fast-moving globulins. Similar influences may operate in reflecting traumatic injury during labor or might be connected with the rapidly occurring involution of uterine musculature known to take place following delivery, coincident with the regressive change in plasma volume.

Stern and Reiner (45) pointed out that relative protein concentrations "computed from electrophoretic data are affected to some extent by the ionic strength and the protein concentration" and emphasized the limited number of normal values in the literature, the marked individual differences in them, and the need for large series of observations under closely controlled and uniform conditions to demarcate more accurately between normal and abnormal or pathological variations. Although Lagercrantz (5) used a phosphate buffer at a $\mathrm{pH}$ of 7.7 and an ionic strength of 0.15 in his study of serum in pregnancy, the relative values for the various component proteins showed changes similar to those reported by Longsworth and co-workers (4) and to those shown in Table I.

Foster (46), on the basis of early chemical analyses, explained the increase in fibrin postpartum as a probable result of trauma incident to birth, after Foster and Whipple (47) had concluded that hemorrhage led to a fibrin increase.
The mean fibrinogen values found in this study indicate a consistent increase in that protein during pregnancy with higher values five to six days postpartum followed by a decrease to below the non-pregnant level six to 12 weeks after delivery. Values for the four -women whose levels were determined within 24 hours after their infants were born show that the greater part of the increase in fibrinogen occurred prior to delivery, with maximum values during the first day postpartum and decreases by five to six days after delivery. At six to 12 weeks postpartum the values were essentially those of the preconceptional state. Apparently, instead of a fibrin increase in response to trauma during delivery, a relative increase in fibrinogen starts early in pregnancy and continues until delivery, perhaps in anticipation of blood losses and trauma during the partum period.

The return of the plasma protein pattern toward normal is almost complete by six to 12 weeks postpartum. The concentrations of total protein, albumin, and gamma globulin have risen and of the other globulins are reduced. This return to normal seems to be uninfluenced by lactation or its suppression, or the early re-establishment of menstruation, for mothers in none of these categories showed variations which could be related to those conditions. This negative finding supports the belief that protein demands as such are not the basis for altered electrophoretic patterns in pregnancy.

Changes in the blood proteins during pregnancy have been the subject of numerous investigations. Until recently, however, the reports have presented only the results of chemical determinations of total protein or changes in the albumin, total globulin, and fibrinogen components $(40,48)$ as revealed by precipitation procedures. Electrophoretic analysis of the proteins in serum or plasma provides a more detailed and reliable picture of this labile biological system than do other methods used heretofore $(3,13,45,49,50)$, although values are frequently lower than those obtained by chemical methods. This new tool not only permits accurate estimation of the albumin/globulin ratio, but also provides quantitative data for four distinguishable components of plasma globulin, exclusive of fibrinogen. 
SUM MARY

This study comprises the results of electrophoretic fractionation of plasma proteins from 93 blood samples, 22 samples being from 12 healthy non-pregnant women, and 71 from 21 mothers during uncomplicated pregnancy, at delivery, and at intervals postpartum. The same subjects were studied at intervals during the reproductive cycle; one participated before conception, during pregnancy, and postpartum and contributed a total of 11 blood samples.

All women were in satisfactory nutritional state as indicated by results of microchemical blood tests (including hemoglobin and protein, vitamin A, carotenoids, vitamin $\mathrm{C}$ and alkaline phosphatase in the blood serum) and by clinical observation.

The data demonstrate characteristic changes of total protein and plasma albumin and globulins $\left(\right.$ alpha $_{1}$, alpha 2 , beta, and gamma fractions, and fibrinogen) during the reproductive cycle. Within the range of values, however, the different women exhibited inherent variations in physiological performance.

The analysis of plasma proteins during the reproductive cycle showed that:

1. The mean values for total plasma protein decreased during pregnancy, the mean amount in the third trimester being 13 per cent below the non-pregnant value.

2. On the basis of the concentration in plasma protein and in plasma there were statistically significant differences among mean values at intervals in the reproductive cycle and mean values for non-pregnant women.

3. Through delivery, plasma and protein concentration trends were consistently downward for albumin and gamma globulin and upward for the alpha $_{1}$, alpha $_{2}$, and beta fractions, and fibrinogen.

4. Five to six days after delivery, means for all protein fractions differed significantly from the averages for non-pregnant subjects, both per 100 gm. of plasma protein and per $100 \mathrm{ml}$. of plasma.

5. Six to 12 weeks postpartum the alpha $a_{1}$ and beta components differed significantly from the non-pregnant average values on the basis of 100

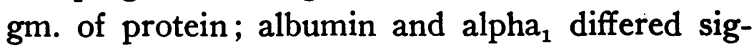
nificantly per $100 \mathrm{ml}$. of plasma. All other variations from preconceptional levels were not statistically significant.

\section{BIBLIOGRAPHY}

1. Mack, H. C., Robinson, A. R., Wiseman, M. E., and Schoeb, E. J., Metabolism of women during the reproductive cycle. XVIII. Electrophoretic patterns of plasma proteins in toxemias of pregnancy. To be published.

2. Coryell, M. N., Beach, E. F., and Robinson, A., Electrophoretic patterns of plasma proteins during pregnancy and following delivery. Federation Proc., 1949, 8, 192.

3. Tiselius, A., Electrophoresis of serum globulin. II. Electrophoretic analysis of normal and immune sera. Biochem. J., 1937, 31, 1464.

4. Longsworth, L. G., Curtis, R. M., and Pembroke, R. H., Jr., The electrophoretic analysis of maternal and fetal plasmas and sera. J. Clin. Invest., 1945, 24, 46.

5. Lagercrantz, C., Electrophoretic analysis of serum in pregnancy and in pregnancy toxemia. Upsala läkaref. förh., 1945, 51, 117.

6. Moore, D. H., DuPan, R. M., and Buxton, C. L., An electrophoretic study of maternal, fetal, and infant sera. Am. J. Obst. \& Gynec., 1949, 57, 312.

7. Scrimshaw, N. S., and Alling, E. L., Electrophoretic findings in normal and abnormal pregnancy. Federation Proc., 1949, 8, 368.

8. Wilson, E. B., Heights and weights of 275 public school girls for consecutive ages 7 to 16 years, inclusive. Proc. Nat. Acad. Sc., 1935, 21, 633.

9. Shuttleworth, F. K., The Physical and Mental Growth of Girls and Boys Age Six to Nineteen in Relation to Age at Maximum Growth. Soc. Research in Child Development, Monograph No. 3, National Research Council, Washington, 1939.

10. Rowe, A. H., The effect of venous stasis on the proteins of human blood serum. J. Lab. \& Clin. Med., 1915-16, 1, 485.

11. Peters, J. P., and Van Slyke, D. D., Quantitative Clinical Chemistry. Vol. II, Methods. The Williams \& Wilkins Company, Baltimore, 1932.

12. Macy, I. G., Nutrition and Chemical Growth in Childhood. Vol. I, Evaluation. Charles C. Thomas, Springfield, IIl., 1942.

13. Longsworth, L. G., Recent advances in the study of proteins by electrophoresis. Chem. Rev., 1942, 30, 323.

14. Longsworth, L. G., The observation of electrophoretic boundaries. Ann. N. Y. Acad. Sc., 1939, 34, 107.

15. Longsworth, L. G., A modification of the schlieren method for use in electrophoretic analysis. J. Am. Chem. Soc., 1939, 61, 529.

16. Tiselius, A., and Kabat, E. A., An electrophoretic study of immune serums and purified antibody preparations. J. Exper. Med., 1939, 69, 119.

17. Hoffman, W., and Kelly, H. J., Applicability of a differential analyzer to the determination of protein fractions by the electrophoretic technic. Proc. Soc. Exper. Biol. \& Med., in press. 
18. Moore, D. H., Roberts, J. B., Costello, M., and Schonberger, T. W., Factors influencing the electrophoretic analysis of human serum. J. Biol. Chem., 1949, 180, 1147.

19. Longsworth, L. G., and MacInnes, D. A., Electrophoretic study of nephrotic sera and urine. J. Exper. Med., 1940, 71, 77.

20. Armstrong, S. H., Jr., Budka, M. J. E., and Morrison, K. C., Preparation and properties of serum and plasma proteins. XI. Quantitative interpretation of electrophoretic schlieren diagrams of normal human plasma proteins. J. Am. Chem. Soc., 1947, 69, 416.

21. Longsworth, L. G., and MacInnes, D. A., The interpretation of simple electrophoretic patterns. J. Am. Chem. Soc., 1940, 62, 705.

22. Abramson, H. A., Moyer, L. S., and Gorin, M. H., Electrophoresis of Proteins and the Chemistry of Cell Surfaces. Reinhold Publishing Corp., New York, 1942.

23. Heller, V. G., and Paul, H., Changes in cell volume produced by varying concentrations of different anticoagulants. J. Lab. \& Clin. Med., 1934, 19, 777.

24. Dieckmann, W. J., and Wegner, C. R., Studies of the blood in normal pregnancy. II. Hemoglobin, hematocrit and erythrocyte determinations and total amount of variations of each. Arch. Int. Med., 1934, 53, 188.

25. Dieckmann, W. J., and Wegner, C. R., Studies of the blood in normal pregnancy. III. Hemoglobin and cell volume coefficients; erythrocyte volume, hemoglobin content and concentration; color, volume and saturation indexes. Arch. Int. Med., 1934, 53, 345.

26. Wintrobe, M. M., Clinical Hematology. Lea \& Febiger, Philadelphia, 1946, 2nd edition.

27. Hoel, P. G., Introduction to Mathematical Statistics. John Wiley \& Sons, Inc., New York, 1947, p. 145.

28. Kaucher, M., Moyer, E. Z., Harrison, A. P., Thomas, R. U., Rutledge, M. M., Lameck, W., and Beach, E. F., Nutritional status of children. VII. Hemoglobin. J. Am. Dietet. A., 1948, 24, 496.

29. Lowry, O. H., and Hunter, T. H., The determination of serum protein concentration with a gradient tube. J. Biol. Chem., 1945, 159, 465.

30. Lowry, O. H., Lopez, J. A., and Bessey, O. A., The determination of ascorbic acid in small amounts of blood serum. J. Biol. Chem., 1945, 160, 609.

31. Bessey, O. A., Lowry, O. H., and Brock, M. J., The quantitative determination of ascorbic acid in small amounts of white blood cells and platelets. J. Biol. Chem., 1947, 168, 197.

32. Bessey, O. A., Lowry, O. H., and Brock, M. J., A method for the rapid determination of alkaline phosphatase with 5 cubic millimeters of serum. J. Biol. Chem., 1946, 164, 321.

33. Lowry, O. H., and Bessey, O. A., The adaptation of the Beckman spectrophotometer to measurements on minute quantities of biological materials. $\mathrm{J}$. Biol. Chem., 1946, 163, 633.

34. Bessey, O. A., Lowry, O. H., Brock, M. J., and Lopez, J. A., The determination of vitamin A and carotene in small quantities of blood serum. J. Biol. Chem., 1946, 166, 177.

35. Dieckmann, W. J., The Toxemias of Pregnancy. C. V. Mosby Co., St. Louis, 1941.

36. Clifford, S. H., Bain, K., Herbolsheimer, H., Tisdall, F. F., Aldrich, C. A., and Wegman, M. E., Panel discussion: A program to develop and improve facilities for the care of newborn infants-full term and premature. Pediatrics, 1948, 2, 97.

37. Vermehren, E., Plasmaphosphatase während der Gravidität und der Laktation. Acta med. Scandinav., 1939, 100, 254.

38. Macy, I. G., Maternal nutrition and infant health studies. To be published.

39. Dole, V. P., and Braun, E., The electrophoretic patterns of normal plasma. J. Clin. Invest., 1944, 23, 708.

40. Plass, E. D., and Matthew, C. W., Plasma protein fractions in normal pregnancy, labor, and puerperium. Am. J. Obst. \& Gynec., 1926, 12, 346.

41. Caton, W. L., Roby, C. C., Reid, D. E., and Gibson, J. G., 2nd, Plasma volume and extravascular fluid volume during pregnancy and the puerperium. Am. J. Obst. \& Gynec., 1949, 57, 471.

42. McLennan, C. E., and Corey, D. L., Plasma volume late in pregnancy. Am. J. Obst. \& Gynec., 1950, 59, 662.

43. Chanutin, A., and Gjessing, E. C., Electrophoretic analyses of sera of injured dogs. J. Biol. Chem., 1946, 165, 421.

44. Gjessing, E. C., and Chanutin, A., An electrophoretic study of plasma and plasma fractions of normal and injured rats. J. Biol. Chem., 1947, 169, 657.

45. Stern, K. G., and Reiner, M., Electrophoresis in medicine. Yale J. Biol. \& Med., 1946, 19, 67.

46. Foster, D. P., A clinical study of blood fibrin with observations in normal persons, pregnant women and in pneumonia and liver disease. Arch. Int. Med., 1924, 34, 301.

47. Foster, D. P., and Whipple, G. H., Blood fibrin studies. II. Normal fibrin values and the influence of diet. Am. J. Physiol., 1922, 58, 379.

48. Howe, P. E., The function of the plasma proteins. Physiol. Rev., 1925, 5, 439.

49. Petermann, M. L., Young, N. F., and Hogness, K. R., A comparison of the Howe and electrophoretic methods for the determination of plasma albumin. J. Biol. Chem., 1947, 169, 379.

50. Jager, B. V., Schwartz, T. B., Smith, E. L., Nickerson, M., and Brown, D. M., Comparative electrophoretic and chemical estimations of human serum albumin; an evaluation of six methods. J. Lab. \& Clin. Med., 1950, 35, 76. 